\title{
HISTORIA NATURALIS BULGARICA
}

29

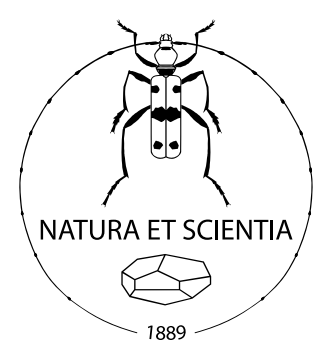

National Museum of Natural History — Bulgarian Academy of Sciences Sofia $\cdot 2018$ 
Published online 19 October 2018 by:

National Museum of Natural History

Bulgarian Academy of Sciences

1 Tsar Osvoboditel Blvd

1000 Sofia, Bulgaria

https://www.nmnhs.com/historia-naturalis-bulgarica/

ISSN 0205-3640 (print)

ISSN 2603-3186 (online)

open 2 Access

Distributed under the Creative Commons Attribution 4.0 International License (CC BY 4.0) 


\section{Contents}

Nedko Nedyalkov, Georgi Popgeorgiev, Anna Staneva

Updated distribution of the elusive Roach's mouse-tailed dormouse, Myomimus roachi Bate, 1937 (Mammalia:

Rodentia: Gliridae) in Bulgaria

Borislav Guéorguiev, Ottó Merkl, Michael Schülke, Hans Fery, Valentin Szénási, David Král, Zbyněk Kejval, Tamás Németh, Dezső Szalóki

Coleoptera (Insecta) from Ashgabat City and Köýtendag Nature Reserve, with nine first records for Turkmenistan 


\title{
Updated distribution of the elusive Roach's mouse-tailed dormouse, Myomimus roachi Bate, 1937 (Mammalia: Rodentia: Gliridae) in Bulgaria
}

\author{
Nedko Nedyalkov ${ }^{1}$, Georgi Popgeorgiev², Anna Staneva ${ }^{3}$
}

1 National Museum of Natural History, Bulgarian Academy of Sciences, 1 Tsar Osvoboditel Blvd, 1000 Sofia, Bulgaria, nedko@nmnhs.com

2 National Museum of Natural History, Bulgarian Academy of Sciences, 1 Tsar Osvoboditel Blvd, 1000 Sofia, Bulgaria, georgi.popgeorgiev@gmail.com

3 BirdLife International, Cambridge, UK, staneva.anna@gmail.com

\begin{abstract}
Myomimus roachi is one of the rarest and least studied mammals of the Western Palearctic. It is rare and sparsely distributed in the Southeastern Balkans and Western Anatolia. After its initial finding in 1959, the species was recorded only sporadically. All available data for the species distribution in Bulgaria are summarised and three new country records are reported, which all together increases the number of squares on the $10 \times 10 \mathrm{~km}$ grid where the species has been recorded to 24 . The current species habitats and threats are discussed.
\end{abstract}

Keywords: Myomimus roachi, Bulgaria, distribution, threats, conservation

\section{Introduction}

In Europe, five species of dormice are found. The rarest, the Roach's mouse-tailed dormouse (Myomimus roachi), occurs only in the Southeastern Balkans and in several isolated localities in Western Anatolia. It is one of the rarest and least known mammal species in the Western Palearctic (Kryštufek, 2008). Peshev et al. (1960) reported the mouse-tailed dormouse as a new member for the European fauna under the name $M$. personatus subsp. $n$. on the base of several specimens caught in Southeastern Bulgaria. Thereafter the species was found in the neighbouring Turkish Thrace and along the Western Anatolian coastline (Mursaloğlu, 1973; Kurtunur, 1975). Unlike the rest of the European dormice, the mouse-tailed dormouse avoids forest habitats. It has been found in vineyards, on the edge of maize and cereal fields and in arable lands with sparse old trees (oak, peer and walnut trees; Peshev et al., 1960; Kryštufek \& Vohralík, 2005).

Bulgarian zoologists had caught the mouse-tailed dormouse predominantly on the ground surface (at that time snap traps were set only on the ground) and supposed that it was ground dwelling similar to its relative living in the Kopet Dag Mountain in Turkmenistan (Peshev et al., 1960). Later, in 1970s and 1980s in Turkish Thrace the species was captured mainly on trees (Kurtonur \& Özkan, 1990).

The Roach's mouse-tailed dormouse is a protected species (Annexes 2 and 3 of the Bulgarian Biological Diversity Act; VU in the Bulgarian Red Data Book (Popov, 2015); Annex 2 of Council Directive 92/43/ EEC or the Habitats Directive). The latest data for its distribution are summarised by Milchev \& Georgiev (2012). Its biology and ecology are still poorly studied and generally unknown, no specific research has been 


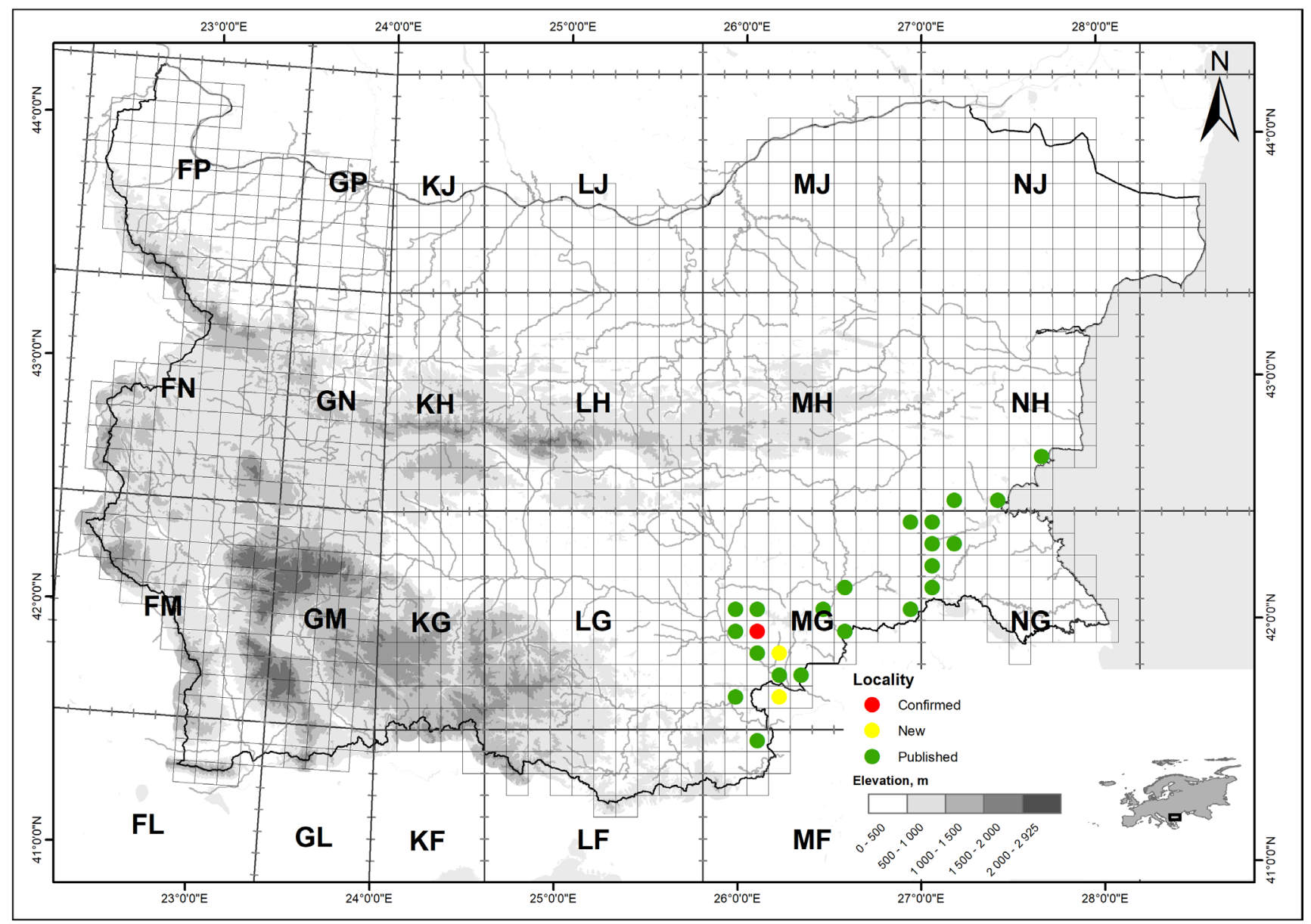

Fig. 1. Current distribution of Myomimus roachi in Bulgaria.

done on the species in Bulgaria. The species is occasionally recorded during faunistic surveys; the most recent records come from studies on the diet of owls. So far, 36 dormice have been caught and 20 have been found in the diet of owls.

\section{Material and methods}

The bulk of data were collected in 2011-2012 during the project for mapping species within Natura 2000 network. Within this project, all known locations until 2010 have been checked by live-trapping: Sherman and Longworth traps (baited with peanut butter, apple, sunflower seeds) were set in suitable habitats. Traps were set on the ground surface and on some old trees: oaks (Quercus sp.), walnut trees (Juglans regia) and pear trees (Pyrus communis) at a height of 1.5-2 m. About 2000 trap-nights were realised. As an addition- al method for species detection, pellets from the barn owl (Tyto alba) from 17 localities and the little owl (Athene noctua) from two localities were collected. Pellets were drained and after that carefully cleaned; bones, skulls and jaws were separated and used for determination of mammals. The minimum number of individuals (MNI) was identified by the maximum count of fragments identified from the left and right mandibula, the maxilla or separate teeth. A total of 21 species were identified from 4400 small mammals in the diet of Tyto alba and 13 in Athene noctua. Livetrapping was also done in the summers of 2016 and 2017.

The study area encompassed the territory of Southeastern Bulgaria and the species distribution is presented using squares of the $10 \times 10 \mathrm{~km}$ Military Grid Reference System grid (MGRS). We combined all previously unpublished observations and georeferenced published data into a GIS database, to update 


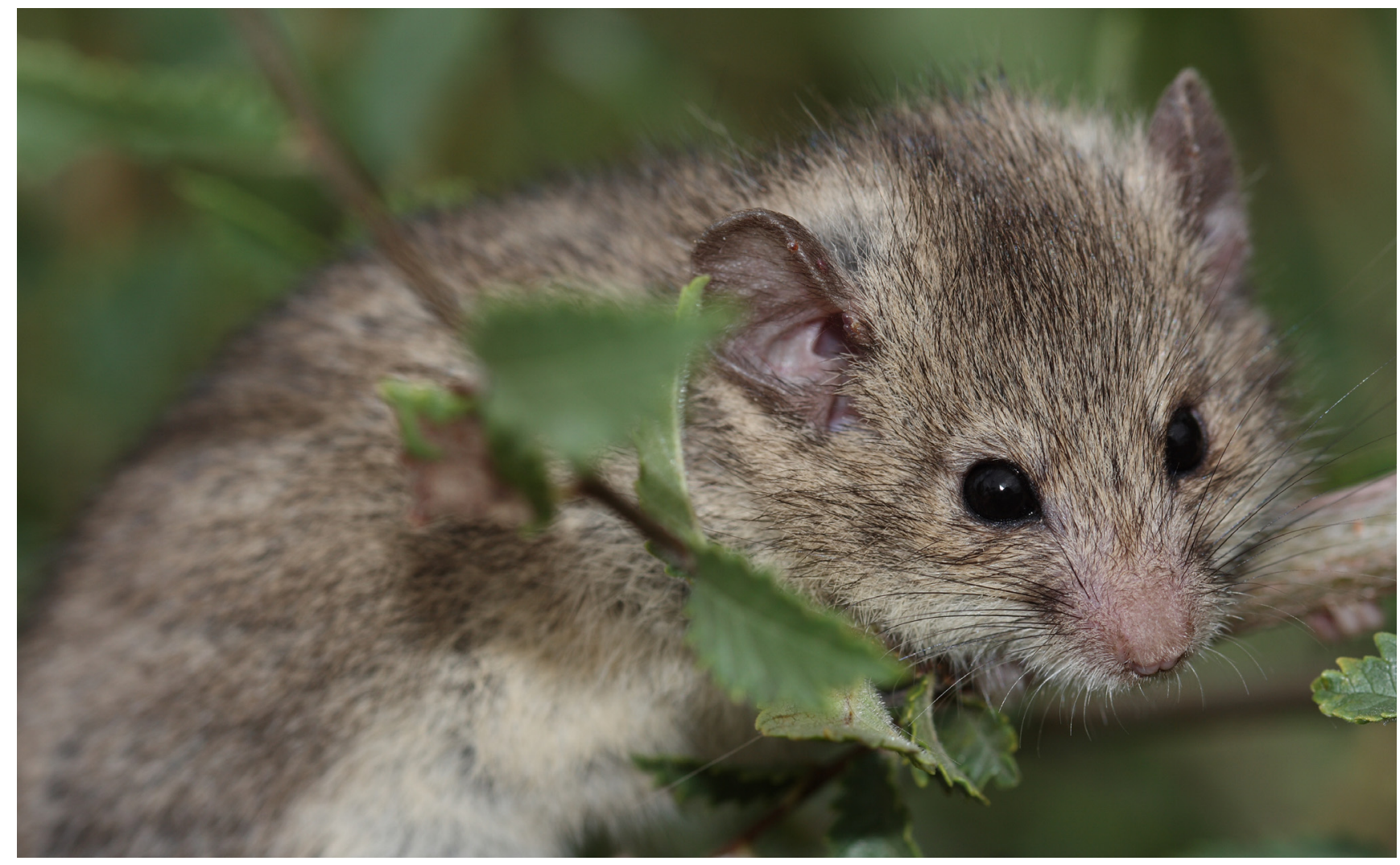

Fig. 2. Roach's mouse-tailed dormouse caught in 2017.

the current known distribution of the Roach's mousetailed dormouse.

\section{Results}

The species was not caught in traps during the 2011-2012 field seasons, despite the efforts (more than 2000 trap-nights). However, it was found in the barn owl pellets. Remains from $M$. roachi have been found in Generalovo and Izvorovo villages (Popov \& Nedyalkov, 2013). At both locations, M. roachi was presented by a single specimen found among 151 $(0.7 \%)$ and $356(0.3 \%)$ prey items of small mammals, respectively. The mouse-tailed dormouse represented a negligible part of the diet of T. alba $-0.045 \%$ (from 4400 prey items) in Southeastern Bulgaria, which was close to the previously reported proportions (Milchev \& Georgiev, 2012).

During faunistic surveys in 2017 in the region of the Sakar Mountain (MG33; Fig. 1) one adult female of $M$. roachi was caught by trapping on 6 May 2017. The specimen had the following measures (in $\mathrm{mm}$ ): body length -96 , tail -92 , ear height -10 , hind foot -21 and weight $-35 \mathrm{~g}$. After examination, the dormouse was released at the same point where it had been caught. The mouse-tailed dormouse was caught on an old (about 40-50 years old) oak tree (Quercus sp.) at $1.8 \mathrm{~m}$ height. The dominant habitat type in this locality was semi-open grassland with shrubs: blackthorn (Prunus spinosa), Jerusalem thorn (Paliurus spina-christi) and single trees or small forest patches of Quercus sp. (about 40-50 years old) and pear trees (Pyrus communis). This was the first catch of the species since 1978, when an adult mouse-tailed dormouse was caught around Burgas (Gorno Ezerovo Village, now part of the city), leg. Alexander Prostov. The specimen is stored and exhibited in the National Museum of Natural History at the Bulgarian Academy of Sciences, Sofia.

Our findings confirmed the presence of the species in the surroundings of Izvorovo Village, found previously from the region in the remains from the diet of the barn owl (materials of B. Milchev, in Peshev et al., 2004). We present two new localities where the species was recorded: Generalovo Village and MG33 in 


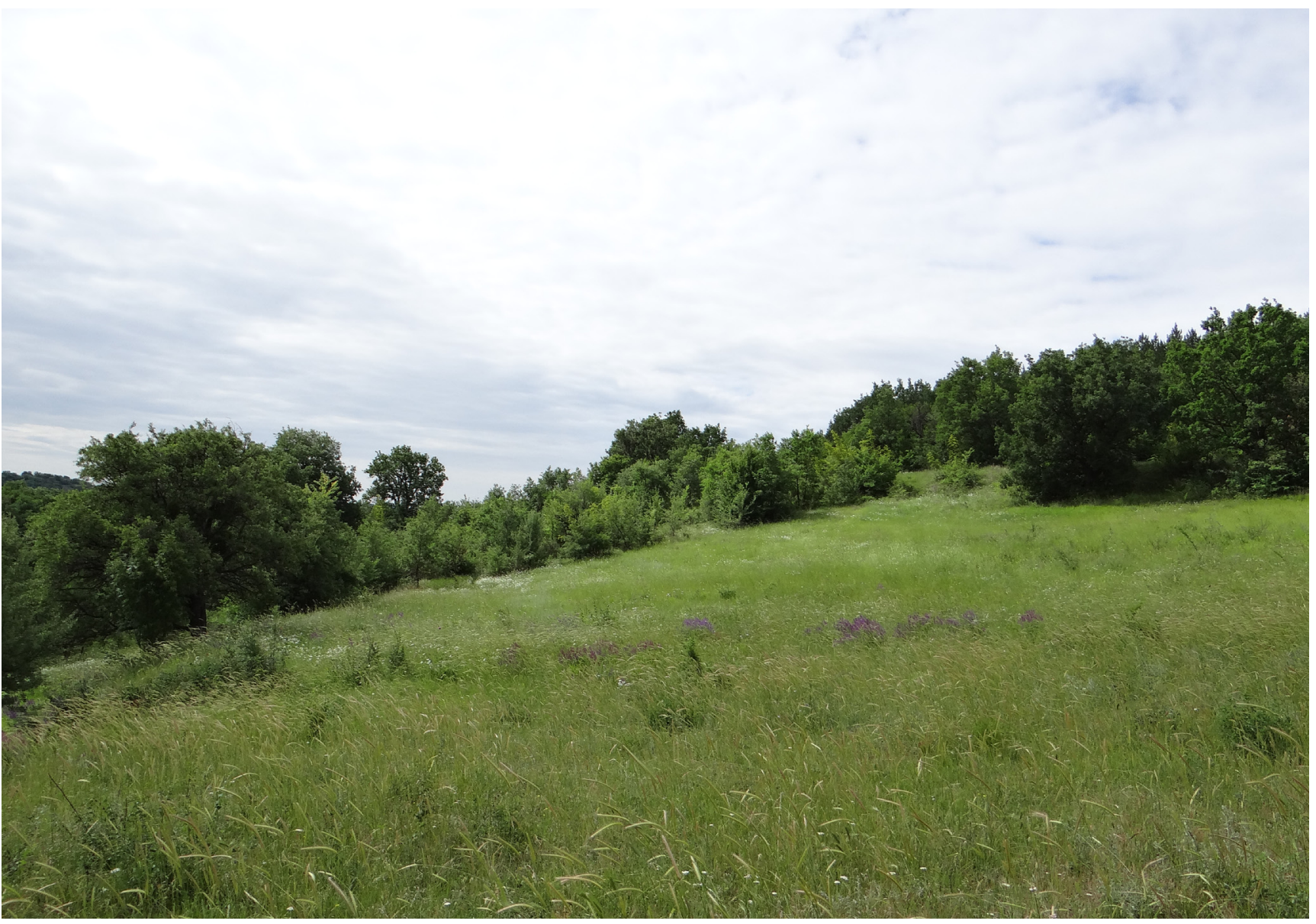

Fig. 3. Habitat of Myomimus roachi in the Sakar Mountain (UTM: MG33), SE Bulgaria.

the Sakar Mountain. The current species distribution is presented on Fig. 1 on the basis of our and previously published data (Heinrich, 1936; Peshev et al., 1960; Markov, 1964; Angermann, 1966; Peshev \& Angelova, 1967; Peshev \& Spassov, 1985; Peshev at al., 2004; Georgiev, 2004; Milchev \& Georgiev, 2012; Nedyalkov, 2013). Altogether, the species was found in 24 MGRS squares $(10 \times 10 \mathrm{~km})$ in Southeastern Bulgaria.

\section{Discussions}

Previous studies have reported that the species is ground-dwelling; it has been caught mainly on the ground surface and, thus, resembles its relative from the Kopet Dag Mountain - M. personatus, the only other known species at that time (Peshev et al., 1960). Habitats in Bulgaria are quite similar with these in Turkish Thrace (Kryštufek \& Vohralík, 2005).
Our data from radio-tracked survey on three mouse-tailed dormice (two female and one male), conducted in Turkish Thrace, have revealed that $M$. roachi spends much of its time on trees and lives in tree-holes and cavities at 1.5-2 $\mathrm{m}$ height, but also crosses wide open areas (150-200 m). It probably spends some time searching for fruits or insects (grasshoppers, crickets) on the ground (N. Nedyalkov, A. Staneva, personal data). In captivity, the species eats willingly insects and different fruits (Buruldağ \& Kurtonur, 2001).

The species habitat has been under anthropogenic pressure for a long time, mainly due to forestry activities: planting and replacing the native habitats - woods of mainly Quercus-Carpinus and the semi-open habitats with shrubs and trees, with alien or atypical species such as the black pine (Pinus nigra), black locust (Robinia pseudoacacia), Atlas cedar (Cedrus atlanti$c a)$. According to the national forestry database, there are multiple plantations at different stages (2-50 years 
old) within the range of $M$. roachi ( 886071.8 ha), with only the black pine covering $37.5 \%$ of this territory.

In the last few years, the species faces a new threat - a new practice for maintaining pastures has appeared in the region of Sakar Mountain and Dervent hills. In order to get subsidies for open pastures, the farmers use heavy-duty shredders to completely remove shrubs and trees. This practice not only changes the habitats through removing the hedgerows and fruit trees, but directly kills and exposes for future depredation other animals, such as tortoises (Testudo sp.), hedgehogs (Erinaceus roumanicus), hares (Lepus europaeus). In addition, fires are common events during the autumn drought and every year they destroy big part from the suitable for the dormouse habitats.

Haas (1959) suggested that the mouse-tailed dormouse has vanished from the Middle East in the near past because of habitat changes - loss of fruit trees (Zizyphus sp.) as a result of intensive human cultivation. The species was quite common and used to be the predominant glirid during the Middle and Late Pleistocene but disappeared suddenly during the Late Bronze Age (Tchernov, 1975).

According to the last mapping project conducted in Bulgaria, the mouse-tailed dormouse is listed for 21 sites from Natura 2000 network, but still $50 \%$ from the known records lie outside the frame of Natura 2000. Its national population is estimated at 2226 adult individuals (Popov \& Nedyalkov, 2013), but one should take it with a grain of salt. This estimation is made based on scarce population data and suitable habitats.

Bulgaria is the only country in the EU responsible to protect this species, but still not a single active conservation or monitoring project on the species has been launched. A big gap exists in our knowledge (for its biology and ecology) about this species, compared to the rest of the European dormice. There is need for urgent conservation efforts preventing further habitat degradation. A monitoring scheme should be launched as soon as possible.

\section{Acknowledgments}

The field survey in 2011-2012 was realised within a project for mapping species and habitats in the frame of Natura 2000 network. The field survey in 20162017 was supported by the project "Restoration and sustainable management of the imperial eagle's for- aging habitats in key Natura 2000 sites in Bulgaria" (LIFE14 NAT/BG/001119) conducted by the Bulgarian Society for the Protection of Birds.

We thank Nikolay Tzankov, Dimitar Plachiyski and Yordan Koshev for their help and company during the fieldwork. Yurii Kornilev checked and improved our English.

This work would not be possible without Ebru and Halim Diker, who shared with us (NN, AN) their experience with Myomimus roachi.

We acknowledge the referees who provided valuable comments on an earlier draft.

\section{References}

Angermann R. 1966 Ein weiterer Fundort von Myomimus personatus Ognev, 1924. Zeitschrift für Säugetierkunde 31: 411.

Buruldağ E., Kurtonur C. 2001 Hibernation and postnatal development of the mouse-tailed dormouse, Myomimus roachi reared outdoor's in a cage. Trakya University Journal of Scientific Research, Ser. B, 2 (2): 179-186.

Georgiev D. 2004 Conservation status of the small mammals (Mammalia: Insectivora, Lagomorpha, Rodentia) in Sakar Mountain (South-eastern Bulgaria). Travaux scientifiques Université de Plovdiv "Paisii Hilendarski", Biologie, Animalia 40 (6): 153-164.

Haas G. 1959 Some remarks on Philistomys roachi Bate. Journal of Natural History, Series 13, 2 (23): 688-690.

Heinrich G. 1936 Über die von mir in Jahre 1935 in Bulgarien gesammelten Säugetiere. Mitteilungen aus den Königlichen naturwissenschaftlichen Instituten in Sofia - Bulgarien 9: 33-48.

Kryštufek B. 2008 Myomimus roachi. The IUCN Red List of Threatened Species 2008: T14087A4389146. http://dx.doi.org/10.2305/ IUCN.UK.2008.RLTS.T14087A4389146.en. Last accessed 2 January 2018.

Kryštufek B., Vohralík V. 2005 Mammals of Turkey and Cyprus. Rodentia I: Sciuridae, Dipodidae, Gliridae, Arvicolinae. Annales Majora, Koper, 292 pp.

Kurtonur C. 1975 New records of Thracian mammals. Säugetierkundliche Mitteilungen 23: 14-16.

Kurtonur C., Özkan B. 1990 New records of Myomimus roachi (Bate 1937) from Turkish Thrace 
(Mammalia: Rodentia: Glirdae). Senckenbergiana Biologica 71 (4): 239-244.

Markov G. 1964 Insektenfressende Säugetiere und Nagetiere in Thrakien (Südbulgarien). In Paspalev G. (ed.) Die Fauna Thrakiens (Sammelwerk). Band I. Verlag der Bulgarischen Akademie der Wissenschaften, Sofia, 19-53 (In Bulgarian).

Milchev B., Georgiev V. 2012 Roach's mouse-tailed dormouse Myomimus roachi distribution and conservation in Bulgaria. Hystrix, the Italian Journal of Mammalogy 23 (2): 67-71.

Mursaloğlu B. 1973 New records for Turkish rodents (Mammalia). Communications de la Faculté des Sciences de l'Université d'Ankara, Ser. C, 17: 213-219.

Nedyalkov N. 2013 New records of some rare rodents (Mammalia: Rodentia) from South-East Bulgaria. ZooNotes 39: 1-4.

Peshev Ts., Dinev T., Angelova V. 1960 Myomimus personatus Ogn. (Myoxidae) - a new species of rodent to the fauna of Europe. Bulletin de l'Institut zoologique de l'Académie des sciences de Bulgarie 9: 305-313. (In Bulgarian).

Peshev Ts., Angelova V. 1967 Insectivora and Rodentia in southern parts of Bulgaria. Annuaire de 1'Université de Sofia, Faculté de Biologie 61 (1): 89-98. (In Bulgarian).
Peshev Ts., Spassov N. 1985 Bulgarian mouse-tailed dormouse, Myomimus roachi bulgaricus Rossolimo, 1976. In: Botev B., Peshev Tz. (eds) Red Data Book of the People's Republic of Bulgaria. Volume 2. Animals. Publishing House of the Bulgarian Academy of Sciences, Sofia, 140-141. (In Bulgarian).

Peshev Ts., Peshev D., Popov V. 2004 Fauna bulgarica. 27. Mammalia. Editio academica, Sofia. (In Bulgarian).

Popov V. 2015 Mouse-tailed dormouse, Myomimus roachi (Bate, 1937). In: Golemansky V. (ed.). Red Data Book of the Republic of Bulgaria. Volume 2. Animals. Bulgarian Academy of Sciences, Ministry of Environment and Waters of Bulgaria, Sofia, p. 233.

Popov V., Nedyalkov N. 2013 The mouse-tailed dormouse (Myomimus roachi) - general report. Natura 2000, Bulgaria, 32 pp. (In Bulgarian) http:// natura2000.moew. government.bg/PublicDownloads/Auto/SDF_REF_SPECIES/2617/2617 Species 102.zip. Last accessed 29 June 2018.

Tchernov E. 1975 Rodent faunas and environmental changes in the Pleistocene of Israel. In: Prakash I., Ghosh D.K. (eds) Rodents in desert environments, Springer, Netherlands, 331-362. 


\title{
Coleoptera (Insecta) from Ashgabat City and Köýtendag Nature Reserve, with nine first records for Turkmenistan
}

\author{
Borislav Guéorguiev ${ }^{1}$, Ottó Merkl ${ }^{2}$, Michael Schülke ${ }^{3}$, Hans Fery ${ }^{4}$, Valentin Szénási ${ }^{5}$, \\ David Král $^{6}$, Zbyněk Kejval ${ }^{7}$, Tamás Németh ${ }^{8}$, Dezső Szalóki ${ }^{9}$
}

1 [Corresponding author] National Museum of Natural History, Bulgarian Academy of Sciences, 1 Tsar Osvoboditel Blvd, 1000 Sofia, Bulgaria, gueorguiev@nmnhs.com

2 Hungarian Natural History Museum, Baross utca 13, H-1088 Budapest, Hungary

3 Museum für Naturkunde, Invalidenstraße 43, D-10115 Berlin, Germany

4 Räuschstraße 73, D-13509 Berlin, Germany

5 Duna-Ipoly National Park Directorate, Költő utca 21, H-1021 Budapest, Hungary

6 Department of Zoology, Faculty of Science, Charles University, Viničná 7, CZ-128 43 Praha 2, Czech Republic

7 Muzeum Chodska, Chodské náměstí 96, CZ-344 01 Domažlice, Czech Republic

8 Hungarian Natural History Museum, Baross utca 13, H-1088 Budapest, Hungary

9 Kálti Márk utca 16, H-1183 Budapest, Hungary

\begin{abstract}
A list of 60 species group taxa of 15 families of the order Coleoptera collected at Ashgabat City and in Lebap Province (Turkmenistan) is presented. Nine species are reported for the first time for the country: Bembidion aeneum Germar, 1823, Chlaenius extensus Mannerheim, 1825, Gyrinus distinctus Aubé, 1838, Bisnius piochardi (Fauvel, 1875), Gabrius hissaricus Schillhammer, 2003, Quedius novus Eppelsheim, 1892, Thinodromus behnei Gildenkov, 2000, Trichophya pilicornis (Gyllenhal, 1810) and Galeruca jucunda (Faldermann, 1836).
\end{abstract}

Keywords: Coleoptera, Turkmenistan, new records, first records

\section{Introduction}

We give a list of beetles collected from two regions of Turkmenistan in May 2015. The first site is the Botanic Gardens in the Ashgabat City and the second one is the Köýtendag Nature Reserve, Köýtendag Mts., south-eastern Turkmenistan. All material was collected by Prof. Pavel Stoev from the National Museum of Natural History, Bulgarian Academy of Sciences, Sofia, during a Rapid Environmental Assessment survey carried out by an international team of zoologists in the Köýtendag Mts.

The new faunistic information is presented concerning the recent data for the distribution of the Palaearctic beetles (see the sources in part "Material and methods"), thus previous faunistic studies in the region are not considered.

Received: 1 August 2018 • Editor: Mario Langourov

\section{Material and methods}

The present study is based on the identification of 245 specimens belonging to 15 families of the order Coleoptera. The arrangement of the families and statuses of the taxa follow the recent editions of the catalogues of the Palaearctic Coleoptera (volumes 4-8, Löbl \& Smetana, 2007-2013 and volumes 1 and 3, Löbl \& Löbl, 2016-2017). The names of authors who identified the species are given with their shortened first name and full surname at each family (in the part "List of taxa").

\section{Description of the localities}

- № 01: Ashgabat City, Botanic Gardens, 37.954N 58.346E, under stones, leaf litter, dense, mostly dry mixed forest, 22.V.2015. 
Guéorguiev et al.
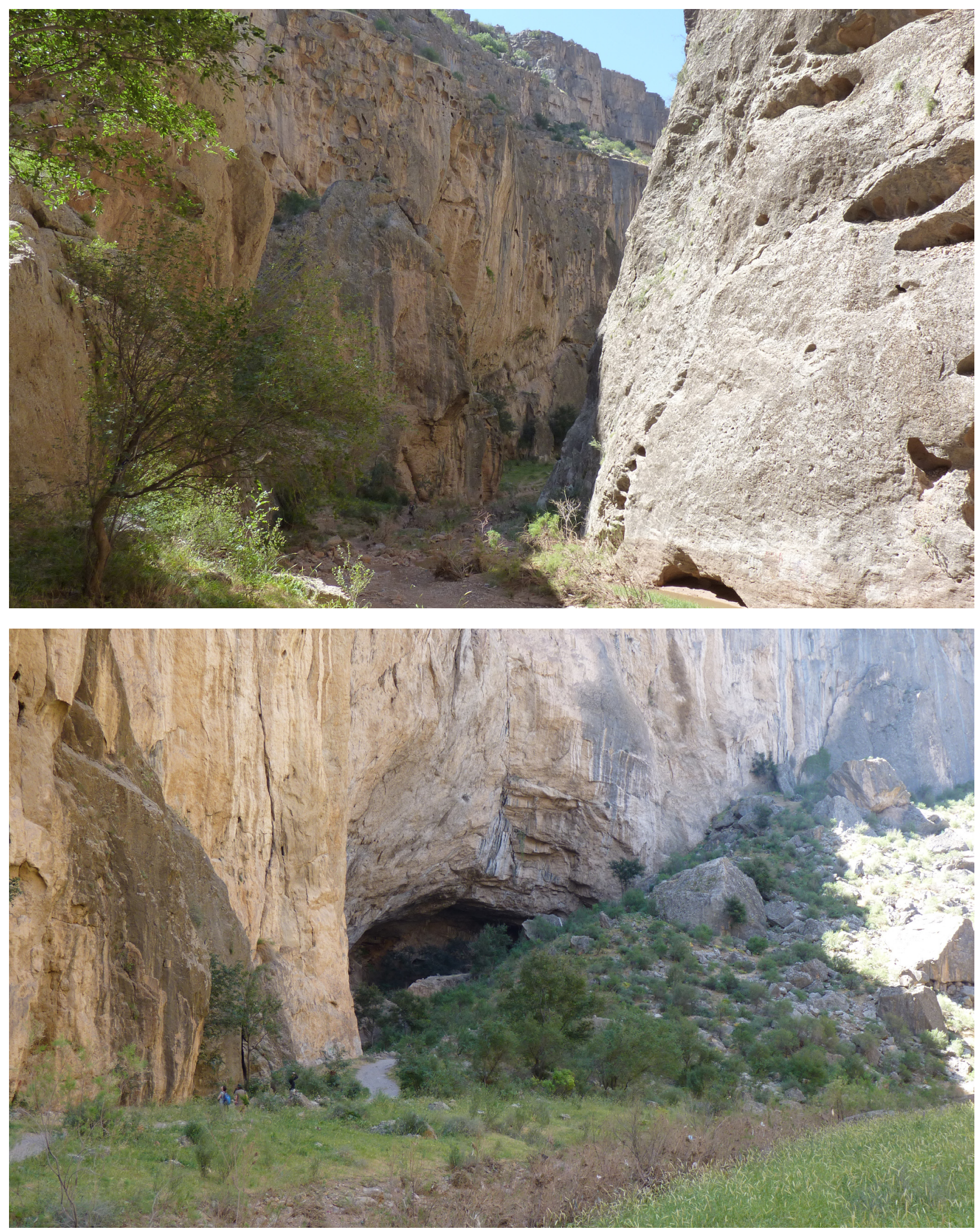

Figures 1-2 (photos courtesy of Pavel Stoev). Locality № 07: the passage Gyrkgyz dere, a collecting site for Chlaenius extensus, Quedius novus, Q. scintillans and Cyphogenia aurita aurita. 


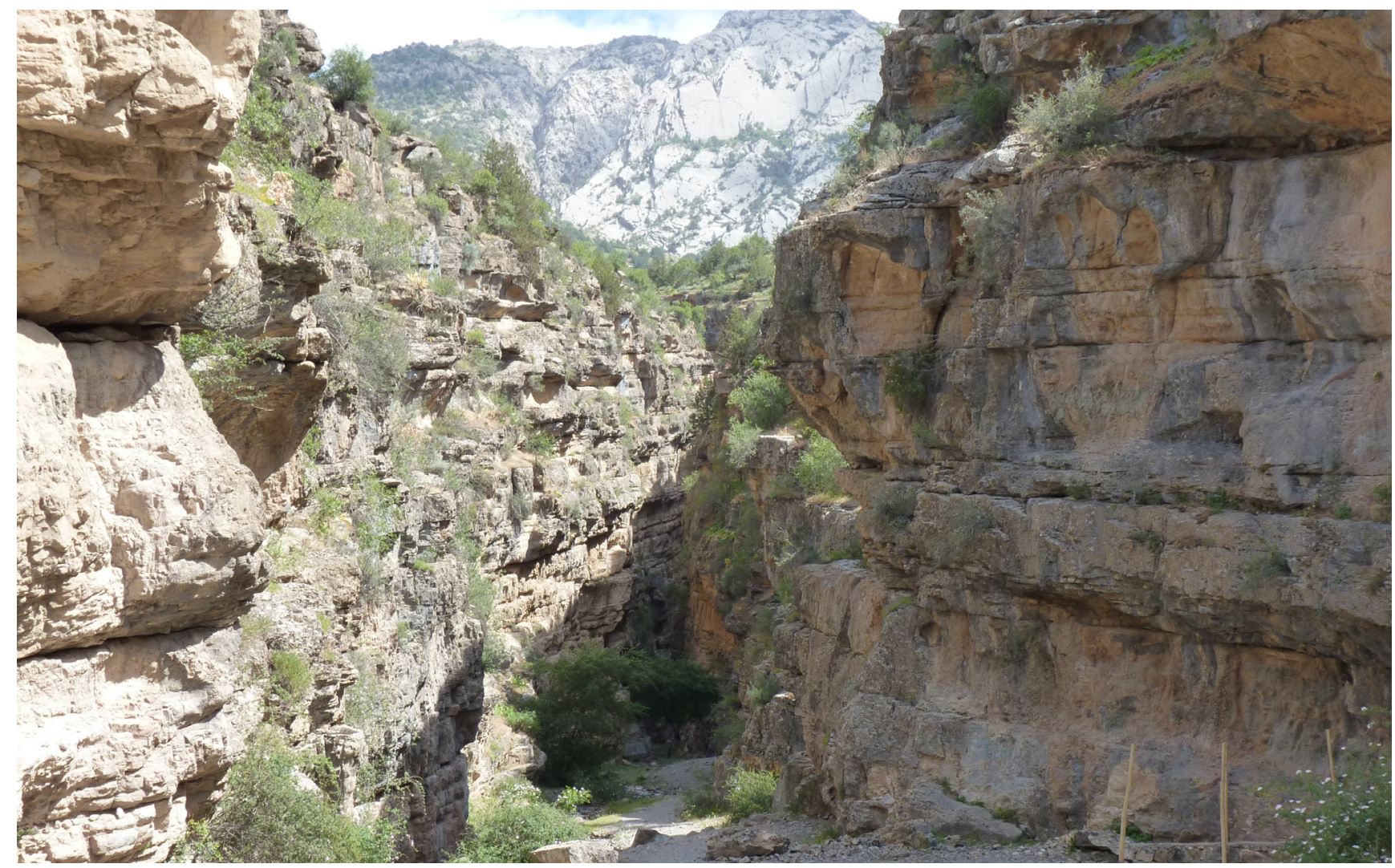

Figure 3 (photo courtesy of Pavel Stoev). Locality № 10: the canyon Umbar dere, a collecting site for three species first reported from Turkmenistan: Chlaenius extensus, Quedius novus, and Galeruca jucunda.

- № 02: Lebap Province, Köýtendag District, Köýtendag Town, 37.508N 65.993E, in close proximity to the river, dry, under stones, 24.V.2015.

- № 03: Lebap Province, Köýtendag District, approx. $10 \mathrm{~km}$ from Köýtendag Town towards Garlyk Village, desert, in close proximity to the road, dry, 24.V.2015.

- № 04: Lebap Province, Köýtendag District, Gurshun Magdanly Village (= Svintsovoy rudnik), around Kaptarhana Cave (Pigeon Cave), 37.828N 66.410E, grassland, 24.V.2015.

- № 05: Lebap Province, Köýtendag District, Bazardepe Village, Köýtendag Nature Reserve Headquarter, 37.762N 66.369E, grassland, 24.V.2015.

- № 06: Lebap Province, Köýtendag District, Köýtendag Mts., from Köýten Village towards Gyrkgyz dere, some 8-9 km from, close to the road, approx. $950 \mathrm{~m}$ a.s.1., under stones, 25.V.2015.

- № 07: Lebap Province, Köýtendag District, Köýtendag Mts., Gyrkgyz dere, along the track, 37.936N 66.595E, under stones, 25.V.2015 (Figs $1-2)$.
- № 08: Lebap Province, Köýtendag District, Köýtendag Mts., Gyrkgyz dere, Kyrkgyz grotto, 37.938N 66.584E, humid, 25.V.2015.

- № 09: Lebap Province, Köýtendag District, Köýtendag Mts., Hojapil Village, around the Dinosaurs tracks Site, 37.941N 66.627E, under stones, 25.V.2015.

- № 10: Lebap Province, Köýtendag District, Köýtendag Mts., Hojapil Village, Umbar dere (the canyon with the waterfall), along the track, 37.936N 66.653E, under stones, 25.V.2015 (Fig. 3).

- № 11: Lebap Province, Köýtendag District, Köýtendag Mts., Hojapil Village, Bash Bulak 2 source, collected from the source and around it, $37.940 \mathrm{~N}$ 66.554E, 25.V.2015.

- № 12: Lebap Province, Köýtendag District, Köýtendag Mts., Daray dere, track from the water tank to the source, $37.781 \mathrm{~N} 66.452 \mathrm{E}$, under stones, 26.V.2015.

- № 13: Lebap Province, Köýtendag District, Köýtendag Mts., Daray dere, disused mine galleries close to the source, 37.778N 66.465E, 26.V.2015. 
Guéorguiev et al.
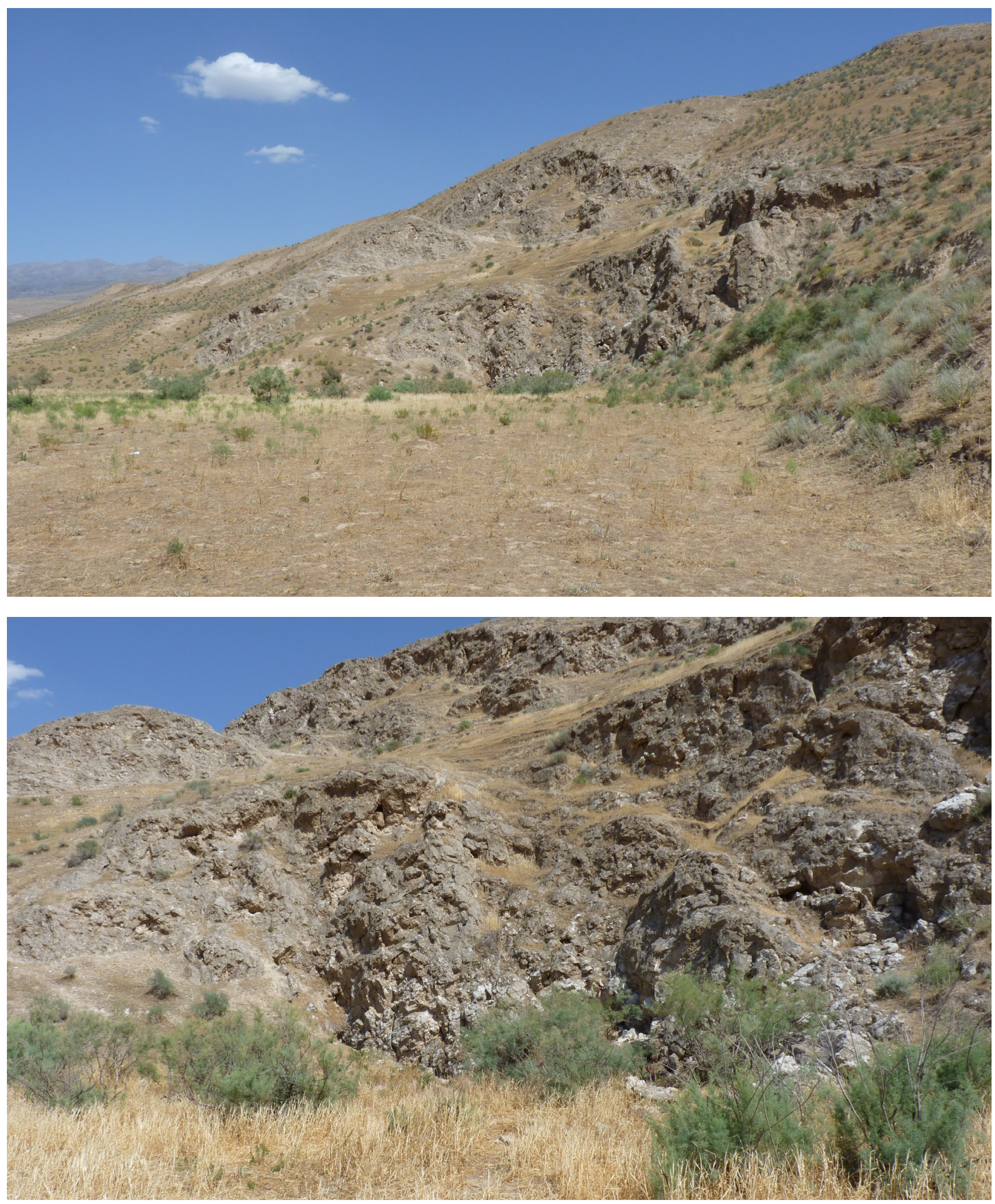

Figures 4-5 (photos courtesy of Pavel Stoev). Localities № 5, № 15 and № 19: grasslands surrounding the Köýtendag Nature Reserve Headquarter, a collecting site for some widely distributed species, such as Apotomus rufithorax, Syntomus fuscomaculatus, Hybosorus illigeri, Augyles turanicus, Cheirodes brevicollis, Gonocephalum rusticum, G. setulosum setulosum, Chaetocnema hortensis, and Sharpia rubida. 
- № 14: Lebap Province, Köýtendag District, Köýtendag Mts., Garlyk Village, Gap Gotan Cave, $37.642 \mathrm{~N} 66.408 \mathrm{E}$, collected mostly in the artificial mine gallery, 27.V.2015.

- № 15: Lebap Province, Köýtendag District, Bazardepe Village, Köýtendag Nature Reserve Headquarter, $37.762 \mathrm{~N} 66.369 \mathrm{E}$, attracted by light at night, 27-28.V.2015.

- № 16: Lebap Province, Köýtendag District, Köýtendag Mts., Garlyk Village, around Gulshirin Cave (= Geofizicheskaya), on shrubs, grass and under stones, 37.673N 66.395E, 28.V.2015.

- № 17: Lebap Province, Köýtendag District, Köýtendag Mts., Garlyk Village, Suuv Oyuk Sinkhole (the sinkhole with the blind loaches), around the sinkhole and in the water, $37.597 \mathrm{~N} 66.406 \mathrm{E}$, 29.V.2015.

- № 18: Lebap Province, Köýtendag District, Köýtendag Mts., Garlyk Village, Khashim Oyuk Cave, $37.642 \mathrm{~N}$ 66.383E, dry, collected mostly in the entrance hall, 29.V.2015.

- № 19: Lebap Province, Köýtendag District, Bazardepe Village, Köýtendag Nature Reserve Headquarter, 37.762N 66.369E, attracted by light at night, 29.V.2015.

- № 20: Lebap Province, Köýtendag District, Gurshun Magdanly Village (= Svintsovoy rudnik), disused mine gallery "Kette-Kamov", 37.862N 66.489E, humid, 30.V.2015.

- № 21: Lebap Province, Köýtendag District, Bazardepe Village, Köýtendag Nature Reserve Headquarter, near Sauk Kamar Cave, 37.758N 66.348E, 30.V.2015.

Note: Entries № 5, № 15 and № 19 refer to the same locality (Figs 4-5), but to different dates and collecting methods.

\section{Abbreviations for specimen depositories}

CHF Hans Fery collection, Berlin, Germany (property of the Naturhistorisches Museum Wien, Vienna, Austria)

DKCP David Král collection, Prague, Czech Republic (deposited in NMPC)

HNHM Hungarian Natural History Museum, Budapest, Hungary (Ottó Merkl)

NMNHS National Museum of Natural History, Sofia, Bulgaria (Borislav Guéorguiev)

NMPC Prague National Museum, Prague, Czech Republic (Jiří Hájek)
SCH Michael Schülke collection, Berlin, Germany (property of the Museum für Naturkunde, Berlin, Germany)

ZKDC Zbyněk Kejval collection, Domažlice, Czech Republic

\section{List of the taxa}

Family Carabidae (det. B. Guéorguiev)

Acinopus (Acinopus) laevigatus Ménétriés, 1832. Material examined: № 06 (1 9 , NMNHS). Distribution: Balkan Peninsula (Croatia, Bulgaria, Greece), Romania, Moldova, Ukraine, southern part of European Russia, Transcaucasia (Armenia, Azerbaijan), northern Levant (Turkey, Israel), Iran, Iraq, Central Asia (from Turkmenistan and Kazakhstan to Gansu, Xizang and northernmost parts of Pakistan and India).

Apotomus rufithorax Pecchioli, 1837. Material examined: № 15 (2 $\widehat{\partial}, 1$ ㅇ, NMNHS). Distribution: Mediterranean region (southern Europe, north-western Africa, Levant), Transcaucasia (Armenia, Azerbaijan), Iran, Iraq, Turkmenistan, Uzbekistan, Afghanistan.

Asaphidion transcaspicum (Semenov, 1889). Material examined: № 10 (1 Ō, NMNHS). Distribution: Bulgaria, Georgia, Azerbaijan, Iran, Central Asia (from Turkmenistan to Xinjiang), eastern Siberia.

Bembidion (Ocyturanes) dyscheres Netolitzky, 1943. Material examined: № 14 (2 $\widehat{\partial}, 1$ ๆ, NMNHS). Distribution: Iran, Central Asia (from Turkmenistan to Tajikistan and Pakistan).

Bembidion (Peryphus) obscurellum turanicum Csiki, 1928. Material examined: № 10 (1 ㅇ, NMNHS). Distribution: Turkey, Iran, Central Asia (from Turkmenistan to Mongolia and Kashmir), eastern Siberia, northern China.

Bembidion (Philochthus) aeneum athalassicum De Monte, 1953. Material examined: № 15 (1 $\precsim, 3$ 우, NMNHS). Distribution: Ukraine, Azerbaijan, Uzbekistan (Neri \& Gudenzi, 2013). Notes: The record from the Köýtendag Nature Reserve is the first one of the halobiont B. aeneum (s.1.) Germar, 1823 from Turkmenistan. According to Paolo Neri (pers. comm.), 
the ssp. athalassicum occurs in environments with clays containing high percentage of $\mathrm{NaCl}$.

Broscus punctatus (Dejean, 1828). Material examined: № 01 (1 Ô, NMNHS). Distribution: southern Levant (Egypt, Sinai), Middle East (Iran, Iraq, Arabian Peninsula), Central Asia (Uzbekistan, Kyrgyzstan, Tajikistan, Afghanistan), Nepal, northern India, south China.

Calathus (Neocalathus) ambiguus ambiguus (Paykull, 1790). Material examined: № 10 ( 2 ふึग, 6 우우, NMNHS). Distribution: Europe, western Siberia, Transcaucasia, northern Levant (Turkey, Syria, Israel), Iran, Central Asia (from Turkmenistan and Kazakhstan to Afghanistan).

Calosoma (Caminaria) maderae dsungaricum Gebler, 1833. Material examined: № 01 (1 9 , NMNHS). Distribution: eastern Mediterranean region (Greece, Turkey, Cyprus, Syria), Romania, Ukraine, southern part of European Russia, Caucasus, Transcaucasia (Armenia, Azerbaijan), Middle East (Iran, Iraq, Kuwait), Central Asia (from Turkmenistan and Kazakhstan to Mongolia, Gansu, Xizang and Pakistan).

Chlaenius (Chlaeniellus) extensus Mannerheim, 1825. Material examined: № 07 (1 $ᄋ$, NMNHS); № 10 (1 ㅇ, NMNHS; Fig. 6). Distribution: Iran, Uzbekistan, Kyrgyzstan, Tajikistan, southern Siberia. Recently, Schnitter (2016) reported "Chlaenius (Chlaeniellus) near extensus" as a new taxon for Mongolia. Notes: First record from Turkmenistan. Mandl (1983) stated that this species and Chl. vestitus (Paykull, 1790) are morphologically very similar and differ only in body size. The same author (ibid.) suggested that the former could be a subspecies of the latter. This needs verification because both species co-occur in Iran and Kopet Dagh (a mountain range situated in north-eastern Iran and south-western Turkmenistan; ibid.; Azadbakhsh $\&$ Nozari, 2015). These territories, as well as the south part of Kazakhstan are perhaps the areas where these two taxa interbreed.

Cymindis (Paracymindis) asiabadense kryzhanovskii Emetz, 1972. Material examined: № 14 (5 ふぇ゙, 1 ㅇ, NMNHS). Distribution: Turkmenistan, Tajikistan.

Eremosphodrus (Rugisphodrus) dvorshaki Casale \& Vereschagina, 1986. Material examined: № 14 (1 วิ,

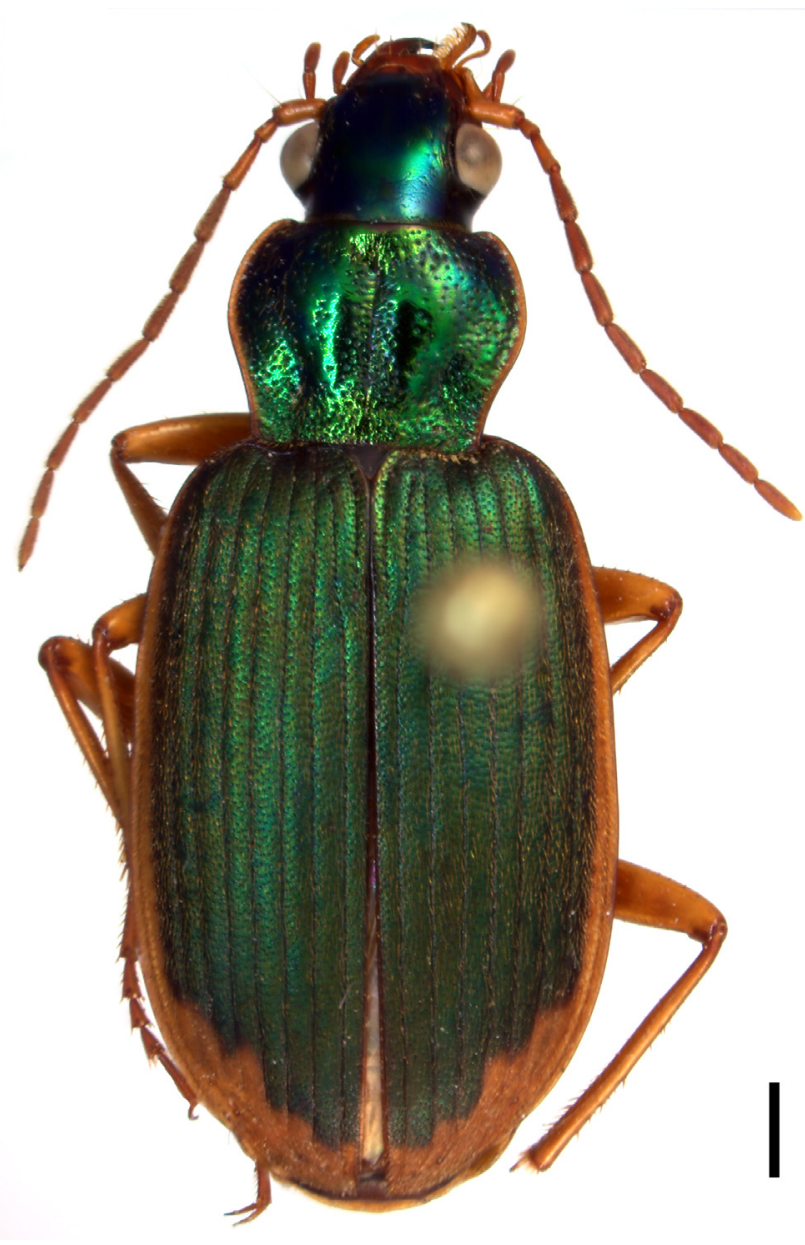

Figure 6. Chlaenius extensus. Scale line $=1 \mathrm{~mm}$.

1 , NMNHS). Distribution: Kazakhstan, Kyrgyzstan, Uzbekistan, Turkmenistan.

Parophonus (Ophonomimus) interstitialis (Reitter, 1889). Material examined: № 15 (1 ㅇ, NMNHS). Distribution: Armenia, Iran, Iraq, Central Asia (from Kazakhstan and Turkmenistan to Pakistan).

Poecilus (Ancholeus) dissors (Tschitschérine, 1893). Material examined: № 15 (1 $\overbrace{}^{\lambda}$, NMNHS). Distribution: Turkmenistan, Kyrgyzstan, Afghanistan.

Syntomus fuscomaculatus Motschulsky, 1844. Material examined: № 15 (2 우, NMNHS); № 21 (1 우, NMNHS). Distribution: Mediterranean region, southern part of European Russia, Caucasus, Transcaucasia, Levant, Middle East (Iran, Iraq, Arabian Peninsula), Central Asia (from Turkmenistan and Kazakhstan to Mongolia and Pakistan), Bhutan, India. 
Trechus (Trechus) quadristriatus (Schrank, 1781). Material examined: № 10 ( 1 ○, 2 qㅇ, NMNHS). Distribution: Europe, north-western Africa, Caucasus, Transcaucasia, Levant, Middle East, Central Asia (from Turkmenistan to Xinjiang).

\section{Family Gyrinidae (det. H. Fery)}

Gyrinus (Gyrinus) distinctus Aubé, 1838. Material examined: № 11 ( 1 $\hat{\jmath}, 1$ ㅇ, CHF; $2 \hat{\jmath}$, NMNHS). Distribution: Europe (except for the northern parts); in Africa: Egypt, Libya and parts of the Afrotropical Region; in Asia: northern Levant (Turkey, Cyprus, Syria, Lebanon), Middle East (Iran, Iraq, United Arab Emirates), Central Asia (Kazakhstan, Uzbekistan, Kyrgyzstan, Mongolia, Afghanistan), China (northern and western regions), Kashmir. Notes: First record from Turkmenistan.

\section{Family Dytiscidae (det. H. Fery)}

Hydaticus (Prodaticus) cf. pictus (Sharp, 1882).

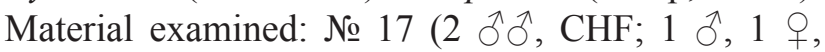
NMNHS). Distribution: Syria, Middle East (Iran, Iraq, Arabian Peninsula), Central Asia (Kazakhstan and Turkmenistan to Pakistan) (Temreshev, 2015).

Hydroporus planus (Fabricius, 1782). Material examined: № 11 (1 q, NMNHS). Distribution: Europe, Morocco, Algeria, Turkey, Lebanon, Iran, Iraq, Turkmenistan, Kazakhstan, Kirgizstan, western Siberia.

Nebrioporus airumlus (Kolenati, 1845). Material examined: № 11 ( 1 ठ, 1 ㅇ, CHF; 1 ○, 2 우, NMNHS). Distribution: Poland, Ukraine, southern part of Russia, Caucasus, Transcaucasia, Turkey, Israel, Iran, Central Asia (Kazakhstan and Turkmenistan to Mongolia and Pakistan), eastern Siberia, large parts of China, Kashmir, northern India.

\section{Family Staphylinidae (det. M. Schülke)}

Achenium quadriceps Eppelsheim, 1889. Material examined: № 15 (7 specimens, NMNHS, 3 specimens $\mathrm{SCH})$; № 19 (1 specimen, $\mathrm{SCH})$. Distribution: southern Russia, Caucasus and Transcaucasia (Armenia, Azerbaijan), Iran, Middle Asia (Afghanistan,
Kyrgyzstan, Kazakhstan, Turkmenistan, Tajikistan, Uzbekistan, China: Xinjian Uygur Zizhiqu) (Assing, 2010).

Bisnius piochardi (Fauvel, 1875). Material examined: № $01(1$ J , SCH). Distribution: from east Turkey to Israel, Syria and Iran (Schülke \& Smetana, 2015). Notes: First record from Turkmenistan. The collected specimen was compared with a male from eastern Turkey.

Gabrius hissaricus Schillhammer, 2003. Material

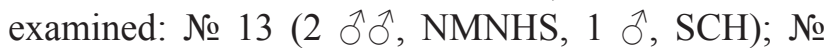
20 (1 $\hat{\jmath}, \mathrm{SCH})$. Distribution: Tajikistan, Turkey (?). Notes: First record from Turkmenistan. The species was described from the Gissar range in Tajikistan. It was later recorded from Erzincan province of Turkey by Özgen \& Khachikov (2013). Since a highly similar species, Gabrius armeniacus Coiffait, 1966, has been recorded from Armenia, this record requires confirmation.

Quedius (Raphirus) novus Eppelsheim, 1892. Material examined: № 07 (1 specimen, NMNHS); № 08 (1 specimen, $\mathrm{SCH}$ ); № 10 (3 specimens, NMNHS, 2 specimens $\mathrm{SCH}$ ); № 13 (1 specimen, $\mathrm{SCH}$ ). Distribution: recorded from Tajikistan and Uzbekistan (Schülke \& Smetana, 2015). Notes: First record from Turkmenistan.

Quedius (Raphirus) scintillans (Gravenhorst, 1806). Material examined: № 07 (1 specimen, SCH). Distribution: western Palaearctic, from North Africa across Europe to the Middle East (Iran, Israel, Lebanon, Syria, Turkey) and Middle Asia (Afghanistan, Turkmenistan, Uzbekistan) (Schülke \& Smetana, 2015).

Sepedophilus rufulus (Hochhuth, 1849). Material examined: № 13 (2 specimens, NMNHS, 1 specimen $\mathrm{SCH})$; № 14 (6 specimens, NMNHS, 4 specimens $\mathrm{SCH})$. Distribution: whole Caucasus and Transcaucasia (Russia, Georgia, Azerbaijan, Armenia, northeastern Turkey), Middle East (Iran, Iraq), Middle Asia (Afghanistan, Turkmenistan, Uzbekistan), northern Pakistan, India (Kashmir) (Schülke \& Smetana, 2015).

Thinodromus behnei Gildenkov, 2000. Material examined: № 14 (1 specimen, NMNHS, 1 specimen SCH). Distribution: western part of Tajikistan (Gissar Alai 
Guéorguiev et al.

and Zarafshan Mountain ranges) (Gildenkov, 2001). Notes: First record from Turkmenistan.

Trichophya pilicornis (Gyllenhal, 1810). Material examined: № 13 (2 specimens, NMNHS, 1 specimen $\mathrm{SCH}$ ). Distribution: whole Palaearctic region (Canary Islands and Spain in the west to east Siberia and the Russian Far East), also adventive in the Nearctic region (Schülke \& Smetana, 2015). Records from the eastern part of the Palaearctic and from the Himalaya (Uttarakhand, Himachal Pradesh) require confirmation. The species lives in leaf litter and under bark. It has also been reported from old mines, where it was probably transported with pit wood. Notes: First record from Turkmenistan.

Family Hybosoridae (det. D. Král \& B. Guéorguiev)

Hybosorus illigeri Reiche, 1853. Material examined: № 15 (1 ๆ, NMNHS). Distribution: Subcosmopolitan (species with an extremely wide distribution, extending from south parts of Europe to India and South Africa including Madagascar; it has been also introduced to large parts of the Nearctic and Neotropical Regions. Widely distributed in Turkmenistan (Nikolajev, 1987).

\section{Family Scarabaeidae (det. D. Král)}

Phaeadoretus comptus (Ménétriés, 1849). Material examined: № 15 (2 specimens, DKCP; 2 specimens, NMNHS); № 19 (1 specimen, NMNHS). Distribution: known from whole Middle Asia, Azerbaijan, Iran and Afghanistan. Widely distributed in Turkmenistan (Nikolajev, 1987).

Pleurophorus apicipennis Reitter, 1892. Material examined: № 15 (1 specimen, DKCP; 9 specimens, NMNHS). Distribution: widely distributed in western Asia (from Turkey and Turkmenistan in the west to the Xinjiang in China in the east).

\section{Family Heteroceridae (det. B. Guéorguiev)}

Augyles turanicus (Reitter, 1887). Material examined: № 19 (1 q, NMNHS; Fig. 7). Distribution: Algeria, Georgia, Levant (Turkey, Syria, Israel), Middle East

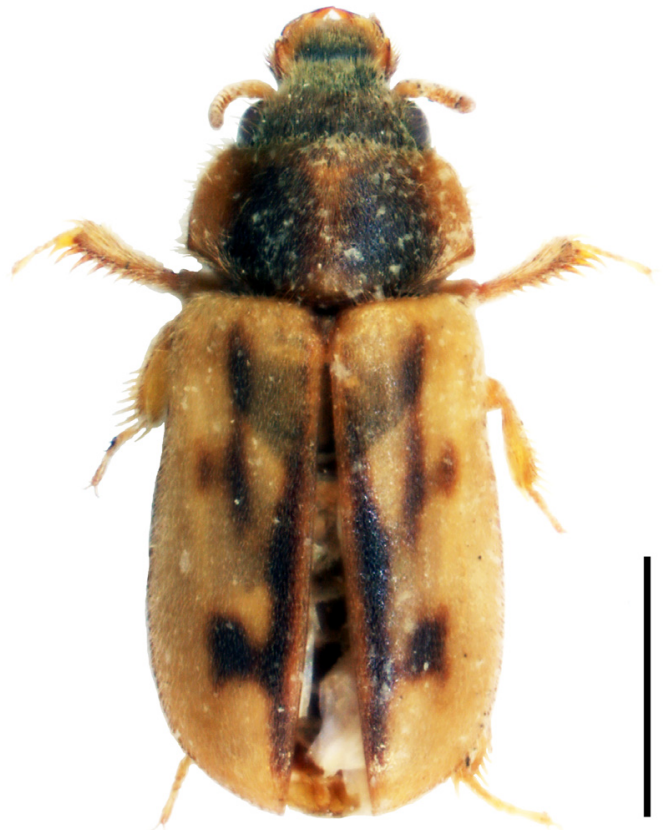

Figure 7. Augyles turanicus, a typical shore beetle. Scale line $=1 \mathrm{~mm}$.

(Iraq, Iran, Saudi Arabia, United Arab Emirates), Kazakhstan, Turkmenistan, Uzbekistan (Mascagni et al., 2016). Extensive bibliographical data about Turanian species were represented by Sazhnev (2017).

\section{Family Elateridae (det. T. Németh)}

Aeoloides figuratus (Germar, 1844). Material examined: № 15 (1 specimen, NMNHS); № 19 (1 specimen, HNHM; 3 specimens, NMNHS). Distribution: Caucasus, Transcaucasia, Arabian Peninsula, Central Asia to Pakistan.

Agriotes (Agriotes) meticulosus Candèze, 1863. Material examined: № 15 (2 specimens, NMNHS). Distribution: Caucasus, Transcaucasia, Arabian Peninsula, Iran to Pakistan.

Family Ptinidae (det. B. Guéorguiev)

Niptus hololeucus (Faldermann, 1835). Material examined: № 14 (29 specimens, NMNHS). Distribution: Cosmopolitan. 
Coleoptera (Insecta) from Ashgabat City and Köýtendag Nature Reserve, with nine first records for Turkmenistan

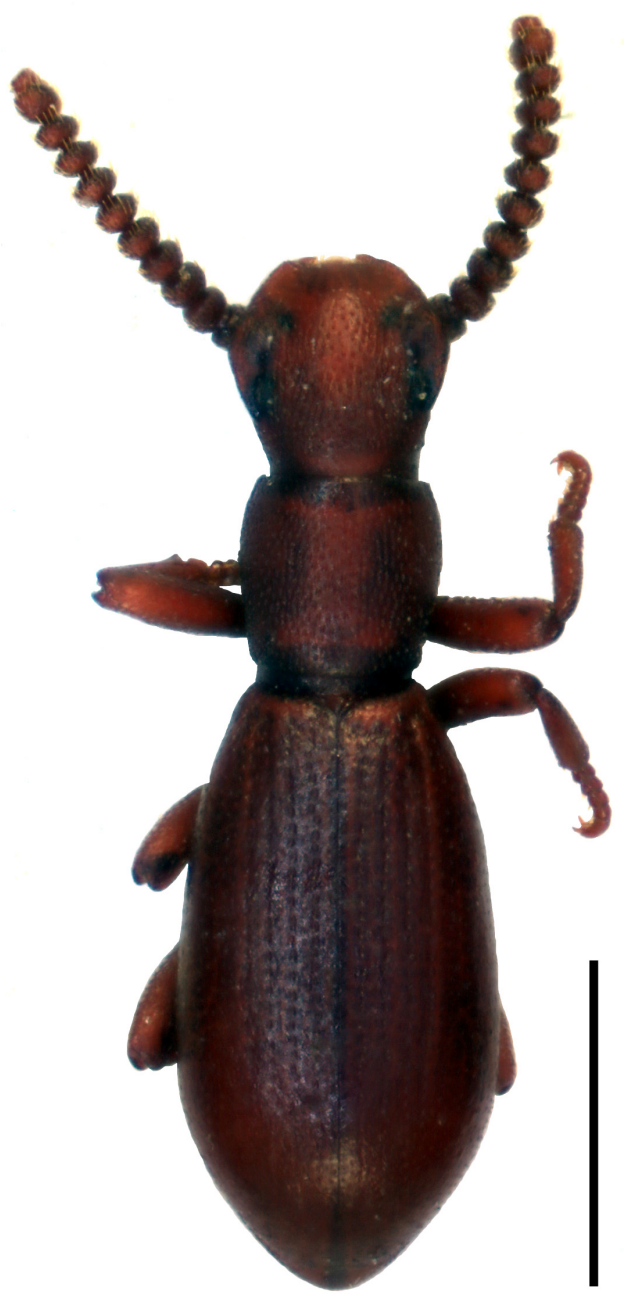

Figure 8. Dichillus seminitidus, a typical nocturnal beetle. Scale line $=1 \mathrm{~mm}$.

Family Coccinellidae (det. O. Merk1 \& B.

Guéorguiev)

Coccinella (Coccinella) septempunctata Linnaeus, 1758. Material examined: № 02 (1 specimen, NMNHS); № 09 (1 specimen, NMNHS); № 12 (1 specimen, NMNHS). Distribution: whole Palaearctic region (south to northern Vietnam); deliberately introduced to North America.

\section{Family Tenebrionidae (det. O. Merkl)}

Adesmia (Adesmia) planidorsis Reitter, 1916. Material examined: № 16 (1 specimen, NMNHS); № 17 (1 specimen, NMNHS). Distribution: Tajikistan, Turk- menistan, Uzbekistan (Löbl et al., 2008; Medvedev \& Nepesova, 1985).

Cheirodes (Pseudanemia) brevicollis (Wollaston, 1864). Material examined: № 15 (1 specimen, NMNHS). Distribution: Mediterranean region (southern Europe, Canary Islands, North Africa, Turkey, Levant), Transcaucasia (Armenia, Azerbaijan), Middle East (Iran, Iraq, Arabian Peninsula), Central Asia (from Turkmenistan to Mongolia, Xinjiang and Pakistan), Sahelian and Saharan parts of Africa (Löbl et al., 2008; Medvedev \& Nepesova, 1985).

Cyphogenia (Cyphogenia) aurita aurita (Pallas, 1781). Material examined: № 07 (1 specimen, NMNHS). Distribution: southern part of European Russia, Afghanistan, Iran, Kazakhstan, Tajikistan, Turkmenistan, Uzbekistan, China (Xinjiang) (Löbl et al., 2008; Medvedev \& Nepesova, 1985).

Dailognatha nasuta (Ménétriés, 1849). Material examined: № 04 (1 specimen, HNHM); № 05 (1 specimen, NMNHS); № 16 (1 specimen, NMNHS). Distribution: Afghanistan, Kazakhstan, Tajikistan, Turkmenistan, Uzbekistan (Löbl et al., 2008; Medvedev \& Nepesova, 1985).

Dichillus (Dichillus) seminitidus Solsky, 1881. Material examined: № 15 (1 specimen, NMNHS; Fig. 8). Distribution: Afghanistan, Kazakhstan, Tajikistan, Turkmenistan, Uzbekistan (Löbl et al., 2008; Medvedev \& Nepesova, 1985).

Gonocephalum (Gonocephalum) rusticum (A. G. O1ivier, 1811). Material examined: № 05 (1 specimen, NMNHS); № 15 (5 specimens, NMNHS). Distribution: Mediterranean region (southern Europe, Canary Islands, North Africa, Turkey, Levant), Transcaucasia (Armenia, Azerbaijan), Middle East (Iran, Iraq, Arabian Peninsula), Central Asia (from Turkmenistan to Mongolia and China) (Löbl et al., 2008; Medvedev \& Nepesova, 1985).

Gonocephalum (Gonocephalum) setulosum setulosum (Faldermann, 1837). Material examined: № 15 (1 specimen, NMNHS). Distribution: Mediterranean region (southern Europe, Canary Islands, North Africa, Turkey, Levant), southern part of European Russia, Caucasus, Transcaucasia, Middle East (Iran, Iraq, Arabian Peninsula), Central Asia (from Turkmenistan 
to Afghanistan), Sahelian and Saharan parts of Africa (Löbl et al., 2008; Medvedev \& Nepesova, 1985).

Leptodes (Paraleptodes) terminassianae G. Medvedev, 1970. Material examined: № 18 (11 fragmented specimens NMNHS, 1 fragmented specimen, HNHM). Distribution: Turkmenistan, Uzbekistan (Löbl et al., 2008; Medvedev \& Nepesova, 1985).

Neopachypterus serrulatus (Reitter, 1904). Material examined: № 12 (1 specimen, NMNHS). Distribution: Afghanistan, Armenia, Azerbaijan, Kazakhstan, Tajikistan, Turkmenistan, Uzbekistan (Löbl et al., 2008; Medvedev \& Nepesova, 1985).

Pimeliocnera gebieni Reitter, 1909. Material examined: № 16 (1 specimen, NMNHS). Distribution: Tajikistan, Turkmenistan, Uzbekistan (Löbl et al., 2008; Medvedev \& Nepesova, 1985).

Pimelipachys laevicollis laevicollis (Reitter, 1893). Material examined: № 04 (1 specimen, HNHM; 2 specimens, NMNHS). Distribution: Kazakhstan, Turkmenistan (Löbl et al., 2008; Medvedev \& Nepesova, 1985).

Omophlus sp. Material examined: № 09 (1 specimen, NMNHS).

Opatroides punctulatus parvulus (Faldermann, 1837). Material examined: № 15 (2 specimens, NMNHS). Distribution: Afghanistan, Armenia, Azerbaijan, Iran, Tajikistan, Turkmenistan, Turkey, Pakistan, Uzbekistan, western India (Löbl et al., 2008; Medvedev \& Nepesova, 1985).

Thriptera longipilis Reitter, 1895. Material examined: № 03 (1 specimen, NMNHS); № 04 (1 specimen, NMNHS). Distribution: Afghanistan, Tajikistan, Turkmenistan (Löbl et al., 2008; Medvedev \& Nepesova, 1985).

Zophosis (Oculosis) punctata punctata Brullé, 1832. Material examined: № 09 (1 specimen, NMNHS). Distribution: Mediterranean region (southern Europe, North Africa, Turkey, Levant), Transcaucasia (Armenia, Azerbaijan), Middle East (Iran, Iraq, Arabian Peninsula), Central Asia (from Turkmenistan to Xinjiang and Pakistan) (Löbl et al., 2008; Medvedev \& Nepesova, 1985).

\section{Family Meloidae (det. D. Szalóki)}

Ctenopus sinuatipennis (Fairmaire, 1892). Material examined: № 17 (1 specimen, HNHM). Distribution: Turkmenistan, Uzbekistan, China (Xinjiang).

Family Anthicidae (det. Z. Kejval)

Cordicomus margelanicus (Pic, 1893). Material ex-

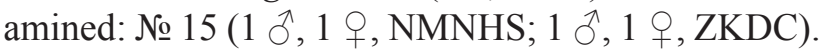
Distribution: Ukraine, southern Russia, Turkey, Syria, Azerbaijan, Iran, Iraq, Central Asia (from Turkmenistan to Mongolia and Afghanistan) (Chandler et al., 2008). Notes: In the Palaearctic catalogue (Chandler et al. 2008), the species is listed under Cordicollis Marseul, 1879 but is to be treated as Cordicomus Pic, 1894 (ICZN 2016, Opinion 2377).

Cyclodinus reitteri (Pic, 1892). Material examined:

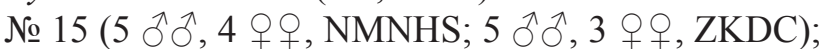

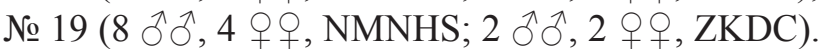
Distribution: southern Russia, Azerbaijan, Syria, Turkmenistan, Uzbekistan, Afghanistan (Chandler et al., 2008).

Family Chrysomelidae (det. B. Guéorguiev)

Chaetocnema (Chaetocnema) hortensis (Geoffroy, 1785). Material examined: № 19 (1 ㅇ, NMNHS). Distribution: Europe, Macaronesia (Azores, Madeira), Morocco, Tunisia, Levant, Georgia, Azerbaijan, Middle East (Iran, Iraq, Arabian Peninsula), Central Asia (from Turkmenistan to Mongolia), eastern Siberia, Russian Far East, China (Jiangsu).

Galeruca (Galeruca) jucunda (Faldermann, 1837). Material examined: № 10 (1 $\precsim$, NMNHS; Fig. 9). Distribution: Europe (excluding the northern and eastern parts), Caucasus, southern Siberia, Turkey, Azerbaijan, Syria, N Iran, Afghanistan, Mongolia, China (Inner Mongolia, Xizang) (Beenen, 2010; Mirzaei \& Nozari, 2016). Notes: First record from Turkmenistan.

\section{Family Curculionidae (det. V. Szénási)}

Corigetus sp. Material examined: № 09 (1 specimen, NMNHS). 


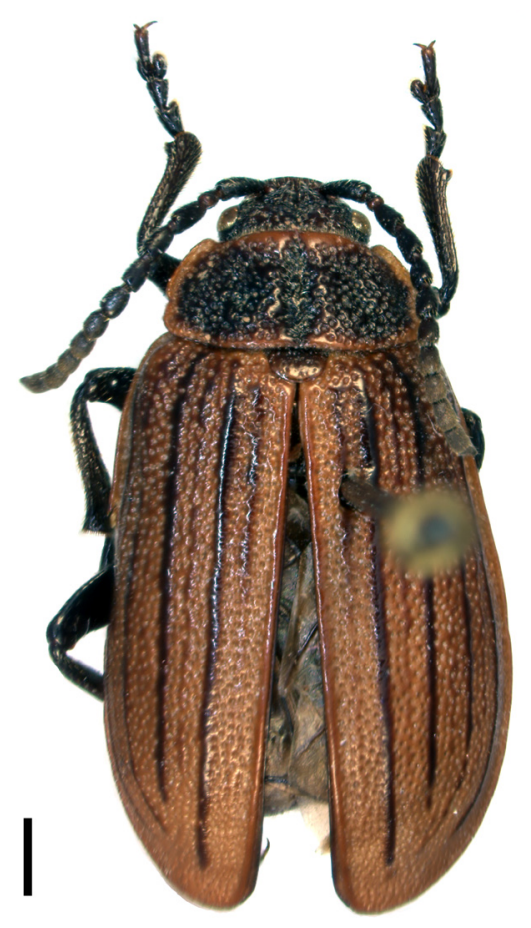

Figure 9. Galeruca jucunda. Scale line $=1 \mathrm{~mm}$.

Hypera (Hypera) postica (Gyllenhal, 1813). Material examined: № 10 (2 specimens, NMNHS). Distribution: whole Europe (including Caucasus and Transcaucasia), North Africa, Turkey to Xinjiang; accidentally introduced to Japan and North America.

Phacephorus nebulosus (Fåhraeus, 1840). Material examined: № 10 (1 specimen, HNHM); № 15 (3 specimens, HNHM; 2 specimens, NMNHS). Distribution: southern part of European Russia, Ukraine, Central Asia to China and eastern Siberia.

Sharpia rubida (Rosenhauer, 1856). Material examined: № 15 (3 specimens, NMNHS); № 19 (2 specimens, NMNHS). Distribution: Mediterranean region (southern Europe, North Africa, Levant), Transcaucasia (Armenia, Azerbaijan), Central Asia (from Turkmenistan, Uzbekistan).

\section{Acknowledgments}

We thank Prof. Dr Pavel Stoev (NMNHS) who collected the material on which this study is based and delivered it to us for examination. Erich Kirschenhofer
(Perchtoldsdorf, Austria) and Paolo Neri (Forlí, Italy) are appreciated for providing Borislav Guéorguiev with information, respectively, about Chlaenius extensus and Bembidion aeneum athalassicum.

\section{References}

Assing V. 2010 A revision of Achenium (Coleoptera: Staphylinidae: Paederinae). Nova Supplementa Entomologica 21: 1-190.

Azadbakhsh S., Nozari J. 2015 Checklist of the Iranian Ground Beetles (Coleoptera; Carabidae). Zootaxa 4024 (1): 1-108.

Beenen R. 2010 Galerucinae. In: Löbl I, Smetana A. (eds) Catalogue of Palaearctic Coleoptera. Vol. 6. Apollo Books, Stenstrup, pp. 443-491.

Chandler D.S., Uhmann G., Nardi G., Telnov D. 2008 Anthicidae Latreille, 1819. In: Löbl I., Smetana A. (eds) Catalogue of Palaearctic Coleoptera. Vol. 5. Tenebrionoidea. Apollo Books, Stenstrup, pp. 421-455.

Gildenkov M.Y. 2001 Phylogenetic relations in the Oxytelinae subfamily. The Palaearctic Thinodromus fauna (Coleoptera: Staphylinidae: Oxytelinae). Publishing House SSPU, Smolensk, 201 pp. (In Russian).

ICZN 2016: Opinion 2377 (Case 3624) A proposal for the rejection of 38 names in anthicidae (Coleoptera): approved. Bulletin of Zoological Nomenclature 73: 65-69.

Löbl I., Löbl D. (eds) 2016 Catalogue of Palaearctic Coleoptera. Vol. 3. Scarabaeoidea - Scirtoidea - Dascilloidea - Buprestoidea - Byrrhoidea. Revised and Updated Edition. Brill, Leiden, Boston, xxviii +984 pp.

Löbl I., Löbl D. (eds) 2017 Catalogue of Palaearctic Coleoptera. Vol. 1. Revised and updated edition. Archostemata - Myxophaga - Adephaga. Brill, Leiden, Boston, xxxiv +1443 pp.

Löbl I., Smetana A. (eds) 2007 Catalogue of Palaearctic Coleoptera, Vol. 4. Elateroidea - Derodontoidea - Bostrichoidea - Lymexyloidea - Cleroidea - Cucujoidea. Apollo Books, Stenstrup, 935 pp.

Löbl I., Smetana A. (eds) 2008 Catalogue of Palaearctic Coleoptera. Vol. 5. Tenebrionoidea. Apollo Books, Stenstrup, 670 pp.

Löbl I., Smetana A. (eds) 2010 Catalogue of Palaearctic Coleoptera. Vol. 6. Chrysomeloidea. Apollo Books, Stenstrup, 924 pp. 
Löbl I., Smetana A. (eds) 2011 Catalogue of Palaearctic Coleoptera. Vol. 7. Curculionoidea 1. Apollo Books, Stenstrup, $373 \mathrm{pp}$.

Löbl I., Smetana A. (eds) 2013 Catalogue of Palaearctic Coleoptera. Vol. 8. Curculionoidea 2. Apollo Books, Stenstrup, 700 pp.

Löbl I., Merkl O., Ando K., Bouchard P., Lillig M., Masumoto K., Schawaller W., Soldati F. 2008 Tenebrionidae. In: Löbl I., Smetana A. (eds) Catalogue of Palaearctic Coleoptera, Volume 5. Tenebrionoidea. Apollo Books, Stenstrup, pp. 105352.

Mandl K. 1983 Ein Beitrag zur Kenntnis einiger Chlaeniinae-(Callistinae-) Formen aus der paläarktischen und der orientalischen Region. (Zugleich erste Auswertung der vom Naturhistorischen Museum in Wien erworbenen ChlaeniinaeSpezialsammlung Ernst Grundmanns). (Carabidae, Col.). 1. Teil. Annalen des Naturhistorischen Museums in Wien (B) 84: 401-447.

Mascagni A., Jäch M., Ostovan H., Ghahari H. 2016 Annotated checklist of Dryopidae and Heteroceridae (Coleoptera: Byrrhoidea) of Iran. Zootaxa, 4144 (3): 354-364. http://doi.org/10.11646/ zootaxa.4144.3.4

Medvedev G.S., Nepesova M.G. 1985 Key to Tenebrionidae of Turkmenistan. Ylym, Ashkhabad, 178 pp. (In Russian).

Mirzaei M., Nozari J. 2016 Catalogue of Iranian subfamily Galerucinae s. str. (Coleoptera: Chrysomelidae). Iranian Journal of Animal Biosystematics 12 (2): 167-180.
Neri P., Gudenzi I. 2013 Note sul genere Bembidion Latreille, 1802, sottogenere Philochthus Stephens, 1828 e descrizione di cinque nuove specie (Insecta Coleoptera Carabidae). Quaderno di Studi e Notizie di Storia Naturale della Romagna 38: 97-179.

Nikolajev G.V. 1987 Scarabaeoidea (Coleoptera) of Kazakhstan and Middle Asia. Izdatelstvo Nauka KazSSR, Alma-Ata, 232 pp. (In Russian).

Özgen I., Khachikov E.A. 2013 New and additional records of Gabrius Stephens, 1829 (Coleoptera: Staphylinidae: Staphylininae) from Turkey and Cyprus. Archives of Biological Sciences 65 (2): 681-683.

Temreshev I.I. 2015 First records of Hydaticus (Prodaticus) pictus Sharp, 1882 (Coleoptera, Dytiscidae) in Kazakhstan. Euroasian Entomological Journal 14 (6): 554.

Sazhnev A.S. 2017 The variegated mud-loving beetles (Coleoptera: Heteroceridae) of the World. Bibliographic Index. (ver. 1.5).

Schnitter P. 2016 Vorläufige Checkliste der Laufkäfer (Coleoptera: Carabidae) der Mongolei 3. Beitrag zur Carabidenfauna der Mongolei. Erforschung biologischer Ressourcen der Mongolei 13: 197220.

Schülke M., Smetana A. 2015 Staphylinidae. In: Löbl I., Löbl D. (eds) Catalogue of Palaearctic Coleoptera. Volume 2. Hydrophiloidea - Staphylinoidea. Revised and updated edition. Brill, Leiden, Boston, pp. 304-1134. 